\title{
My Country
}

Tug Dumbly

\author{
(After Dorothea Mackellar) \\ The love of truth and virtue, \\ Of humanitarian aims, \\ Of decency and justice \\ runs through other veins. \\ Compassion for the suffering \\ Of folk from other skies \\ I know but cannot share it, \\ My love is otherwise. \\ I love a stunted country, \\ A land of weeping shame, \\ Of ragged locked-up strangers' \\ Incarcerated pain. \\ I love her stubborn meanness, \\ Her fat-cat lawyer fees, \\ Her litigatious terror \\ Of bindi-eye and bee. \\ Majestic old-growth forests \\ for whom the woodchip tolls, \\ are chewed up to produce \\ a billion toilet rolls. \\ And stuff the Ozone layer, \\ Those gas emissions thick \\ Can melt the polar ice-caps \\ Like an esky brick.
}


Core of my heart, my country! Land of the handshake gold, Where cash for comment shockjocks fatten up their rolls.

As flashy corporate swindlers find greasy palms to oil, kickbacks top the coffers And bankers scoff the spoils.

Core of my heart, my country! Her pitiless squalid lies Sick at heart surround us Thick as rancid flies But then an election gathers, And we can vote again For some punchless little Judy Whose vision we sustain.

A flinty-hearted country, A wanton, slavish landUnless you love America You're for the Taliban.

It's black and white, cut and dried Penned in our private sty: 'Bugger you, I'm right Jack'the Lucky Country's lie. 